\title{
Mechanisms of Flood-Induced Levee Breaching in Marumori Town during the 2019 Hagibis Typhoon
}

\author{
Nguyen Xuan Tinh ${ }^{1, *} \mathbb{( D}$, Hitoshi Tanaka ${ }^{1} \mathbb{D}$, Gen Abe ${ }^{1}$, Yuka Okamoto ${ }^{1}$ and Kwanchai Pakoksung ${ }^{2}$ \\ 1 Department of Civil Engineering, Tohoku University, 6-6-06 Sendai 980-8579, Japan; \\ hitoshi.tanaka.b7@tohoku.ac.jp (H.T.); gen.abe.r4@dc.tohoku.ac.jp (G.A.); \\ yuka.okamoto.p4@dc.tohoku.ac.jp (Y.O.) \\ 2 International Research Institute of Disaster Science, Tohoku University, 468-1 Aramaki-Aza, \\ Aoba-ku, Sendai 980-0845, Japan; pakoksung@irides.tohoku.ac.jp \\ * Correspondence: nguyen.xuan.tinh.c5@tohoku.ac.jp
}

Citation: Tinh, N.X.; Tanaka, H.; Abe, G.; Okamoto, Y.; Pakoksung, K. Mechanisms of Flood-Induced Levee Breaching in Marumori Town during the 2019 Hagibis Typhoon. Water 2021, 13, 244. https://doi.org/ 10.3390/w13020244

Received: 21 December 2020

Accepted: 15 January 2021

Published: 19 January 2021

Publisher's Note: MDPI stays neutral with regard to jurisdictional claims in published maps and institutional affiliations.

Copyright: (c) 2021 by the authors. Licensee MDPI, Basel, Switzerland. This article is an open access article distributed under the terms and conditions of the Creative Commons Attribution (CC BY) license (https:// creativecommons.org/licenses/by/ $4.0 /)$.
Abstract: Typhoon Hagibis, which occurred at the beginning of October 2019, was one of the largest and most powerful tropical cyclones and was considered to be the most devastating typhoon to hit Japan in recorded history. Extreme heavy rainfall caused massive impacts to Japan in general and to Marumori Town, Miyagi Prefecture in particular. In the present study, the detailed flood characteristics at Marumori Town were investigated by using field observation and numerical simulations. The obtained data immediately after the flood has clearly shown that most levee breaches were caused by the water overflow on the river embankment at the constriction areas such as the tributaries' junction and the intersection of the river embankment. Numerical simulations were performed to investigate the mechanism of levee breaching in Marumori Town. According to the simulation results, the flooding water from the upstream levee breach locations flowed into the paddy field area and caused the levee to breach at the river embankment interaction in the downstream area. A new levee breach criterion in terms of overflow depth and its duration on the river embankment was proposed. In addition, a sensitivity analysis was also performed to understand the effect of the backwater and phase lag of water level rise between the mainstream and tributaries. Although there have been many studies on flood disasters, the typhoon's flood-induced disasters on the river and coastal infrastructures have still remained a big challenge. The present study outcomes provide useful information not only to understand how the river embankment of tributaries is vulnerable to water level rise, but also to support the river authorities to prepare better mitigation plans for future flood disasters.

Keywords: Typhoon Hagibis; flood disaster; Marumori Town; heavy rainfall; levee breach; overflow; backwater

\section{Introduction}

According to the typhoon database by the Japan Meteorological Agency (JMA) from 1951 to 2010 [1], an annual average of 26 typhoons have attacked Japan from the Northwest Pacific Ocean, of which three typhoons have caused significant damage and landfall on the main islands of Japan. Most typhoons hit Japan between May and October, where the later typhoons were often stronger than typhoons earlier in the typhoon season. In the past, catastrophic typhoons have caused many casualties and human losses. For example, Typhoon Isewan in 1959 cost the lives of more than 5000 people [2]. In recent decades, however, the number of people killed by typhoons has been much lower due to the improvement of river protection construction and management.

In recent years, the occurrence of many extreme typhoons that brought recordbreaking rainfall worldwide, in general, and in Japan, in particular, has become more frequent. For example, the heavy rain disaster that occurred from 9-11 September 2015 in the Kanto region and the Tohoku region during the Etau Typhoon and the northern 
Kyushu flood event that occurred from 5-6 July 2017 during the Nanmadol Typhoon that impacted mainly on Fukuoka Prefecture and Oita Prefecture. Furthermore, the extreme flood disaster occurred from 28 June to 8 July 2018 during the Praporoon Typhoon, which caused many landfalls on the Honshu and Hokkaido main islands.

Typhoon Hagibis, starting from 6-13 October 2019, was the strongest typhoon in the last several decades in Japan and caused widespread destruction across mainland Japan. The typhoon brought record-breaking rainfall to many areas. For instance, the Izu Peninsula received $750 \mathrm{~mm}$ of rain, central Tokyo got $392.5 \mathrm{~mm}$, Hakone area was $940 \mathrm{~mm}$, and the Marumori area was nearly $600 \mathrm{~mm}$ within $24 \mathrm{~h}$. The heavy rain resulted in at least 1900 landslides and 135 breaches of river embankment points across 71 rivers in Japan. Typhoon Hagibis also created an extreme storm surge level that caused significant damage to the coastal structures along with the Greater Tokyo and Shizuoka areas, as reported by Shimozono et al. (2020) [3].

The Abukuma River Basin in Miyagi Prefecture was one of the most severely damaged places during Typhoon Hagibis. This was probably due to the typhoon's track resembling the river's mainstream direction from south to north, as seen in Figure 1a. The rainfall at Hippo Station, located upstream of the Abukuma River, received nearly $600 \mathrm{~mm}$ in $24 \mathrm{~h}$, resulting in more than 47 levee breaching locations along the river and its tributaries, especially along the Uchi River, Shin River, and Gofukuya River. Consequently, Marumori Town was severe flooding, causing 10 dead, two injured, and more than 1000 houses were damaged [4].
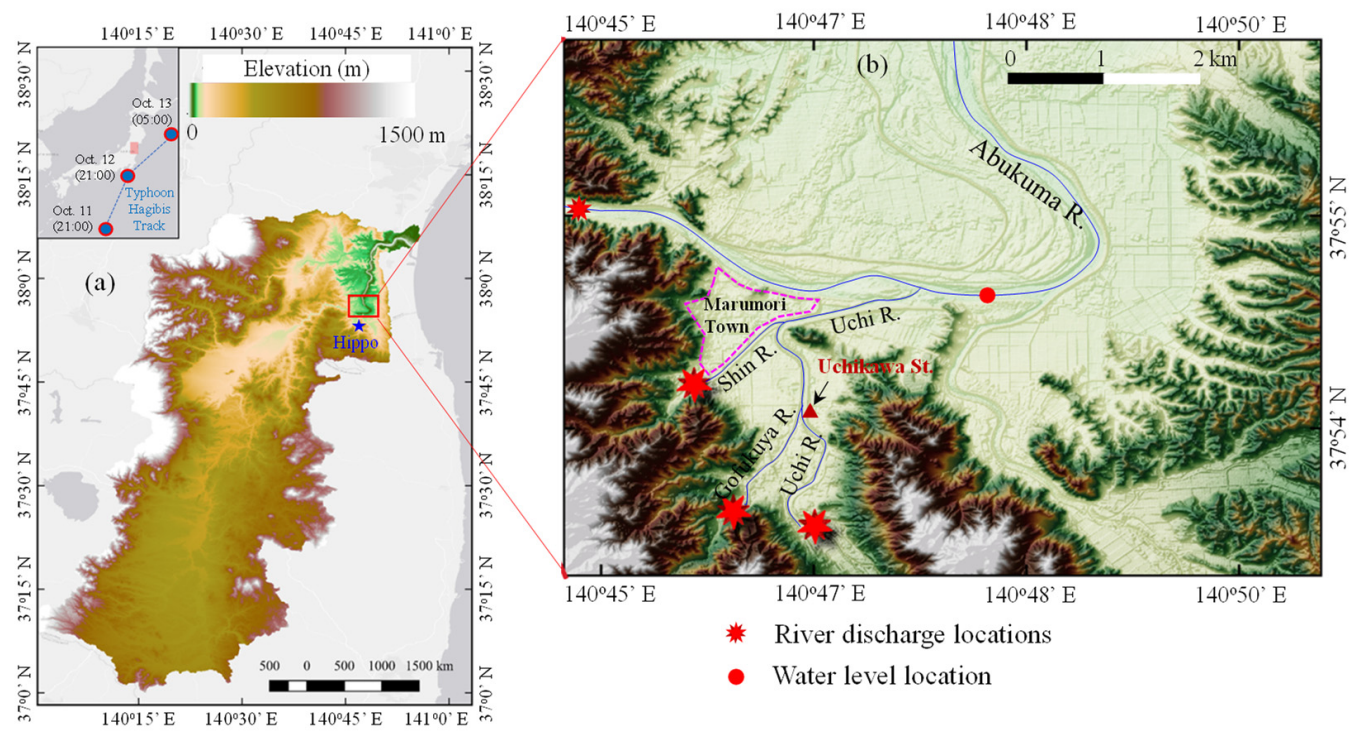

Figure 1. (a) Elevation map of Abukuma River Basin, (b) Location of the Marumori Town.

Although there have been many studies on flood disasters, the typhoon's floodinduced disaster and its impacts on the river and coastal infrastructures have remained a big challenge. The present study investigated levee breaching mechanisms resulting in the severe flood in the Marumori area during Typhoon Hagibis in 2019. The post-field survey was carried out immediately one day after the event on 13 October 2019, with attention to the levee collapse locations. Based on the observation data, the levee breaches at the Uchi River and Gofukuya River's confluence were caused by the river water level rise. Hence, the floodwater from rivers was further expanded into the paddy field and made the levee breach along the right bank of the Shin River and at the confluence of the Shin River and Uchi River in the downstream. A numerical simulation was performed to investigate the mechanism of levee breaching in Marumori Town. According to the simulation results, the floodwater from rivers throughout the levee breach locations upstream of Gofukuya River caused the secondary levee breach at Shin River and Uchi River's confluence. In addition, 
the complete or partial damage of the levee are dependent on the duration of overflow and the maximum overflow water depth. The model results have also shown that the initial overflow locations on the downstream areas occurred at the corner of constricted areas and agreed well with the observed levee breach locations in Marumori Town.

\section{Materials and Methods}

\subsection{Study Area}

Marumori Town is located in the upstream area of the Abukuma River in the Miyagi Prefecture, as shown in Figure 1. Abukuma River is the second-longest river in the Tohoku region. Although the Abukuma River is a Class A river managed by the central government, the upper reaches of the Abukuma River are managed by the prefectural and municipal governments. The Abukuma River Basin has an area of $5390 \mathrm{~km}^{2}$ and a river length of $239 \mathrm{~km}$. There are many tributary rivers along the mainstream of the Abukuma River, of which the Uchi River, Gofukuya River, and Shin River are three tributaries near Marumori Town. The Uchi River has a catchment area of $105.8 \mathrm{~km}^{2}$ and a river length of $18.2 \mathrm{~km}$; the Gofukuya River's catchment area and the length are $23.8 \mathrm{~km}^{2}$ and $2.7 \mathrm{~km}$, while the Shin River has a catchment area of $16.9 \mathrm{~km}^{2}$ and length of $2.1 \mathrm{~km}$. Marumori Town, which has a total area of $273.3 \mathrm{~km}^{2}$ with an estimated population of 13.092, is located on the left side of the Shin River, as shown in Figure 1.

Figure 2a shows the City Hall's historical movement on the aerial photo in 1947 and compared with the latest Google Earth Image in Figure 2b. According to Figure 2, the current residential area and the city hall were relocated from a high-altitude mountain area to the low land paddy field area over the past 73 years. Due to this, Marumori Town is highly exposed to flood disasters if there is an occurrence of typhoon.
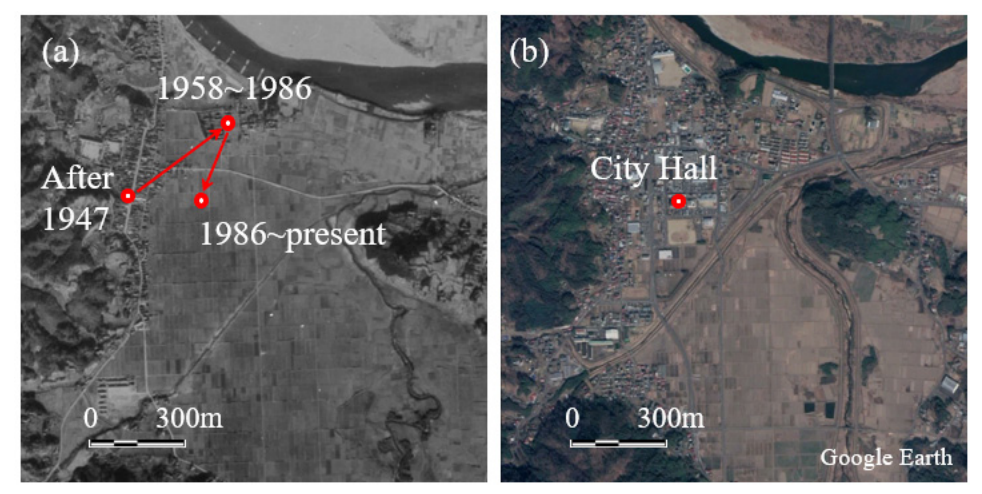

Figure 2. Changing location of the City Hall: (a) on the 1947 aerial photo, (b) on the 2019 Google Earth Image.

\subsection{Data Collection}

In order to achieve the above objectives, the required datasets are the topography data, river discharge, water level, and rainfall data. In the present study, the $5 \mathrm{~m}$-resolution topography data were obtained from the Geospatial Information Authority of Japan (GSI) [5]. The river transects data were provided from the local river authority, as shown in Figure 3. The Abukuma River discharge and water level as well as the rainfall data were obtained from the Ministry of Land, Infrastructure, Transport, and Tourism (MLIT). Figure 4 shows the rainfall data at the Hippo Station, and its location is shown in Figure 1a. The maximum observed hourly rainfall was $74.5 \mathrm{~mm}$, and the cumulate rainfall reached was $587.5 \mathrm{~mm}$ in two days, making a record-breaking rainfall with a return period of around 500 years in this area. 


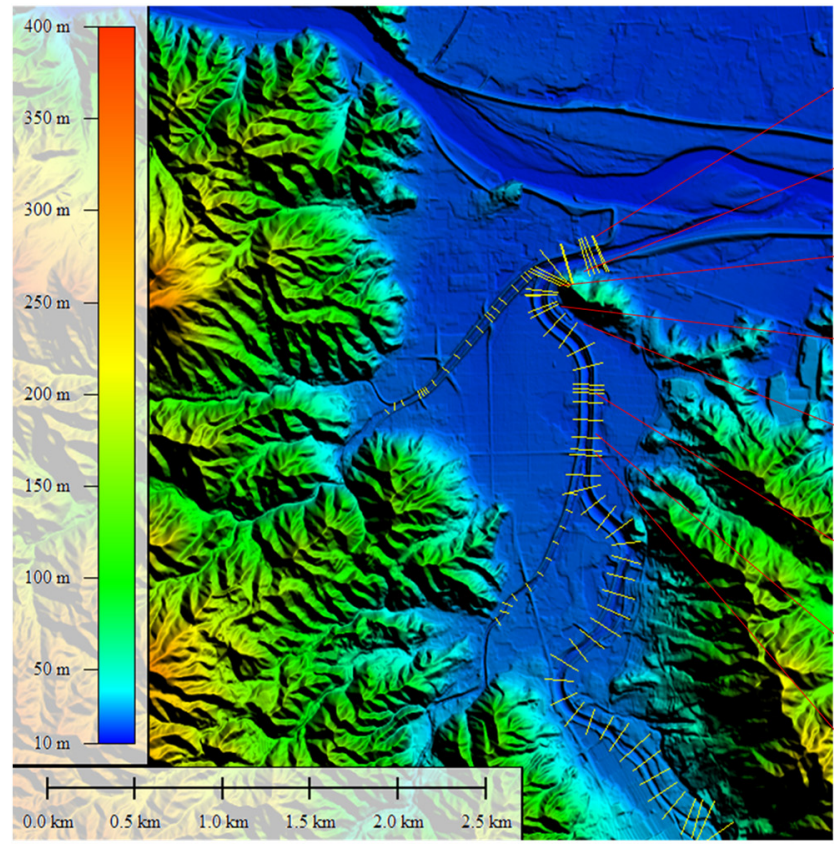

(a) Topography data

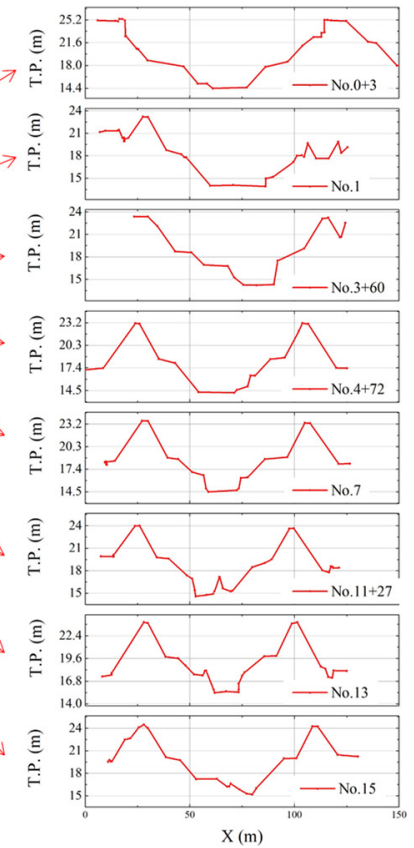

(b) River transection

Figure 3. (a) $5 \mathrm{~m}$-topography data of the Marumori area, (b) measured transects of tributaries.

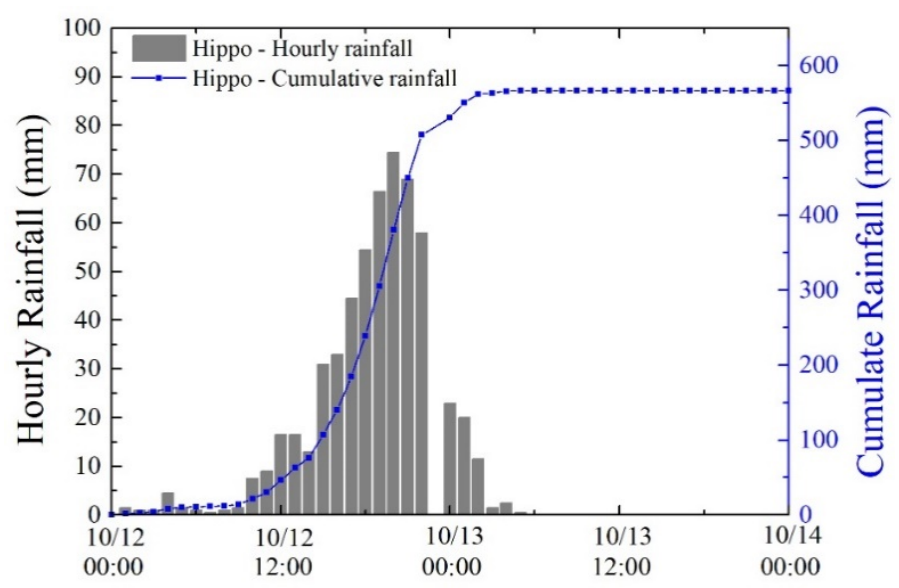

Figure 4. Rainfall data at Hippo Station in the Abukuma River.

\subsection{Numerical Flood Simulation Methodology}

\subsubsection{Rainfall-Runoff-Inundation (RRI) Model}

Since the river discharge measurement data of the tributaries are usually not available, therefore, the two-dimensional rainfall-runoff-inundation (RRI) model was used to calculate the upstream flows of the Uchi, Gofukuya, and Shin Rivers. The RRI model is a newly developed model in two-dimension (Sayama et al. 2010) [6], and the modeling has been separated by slopes and river. The river is positioned on the grid, while grid modeling assumes that the slope and river have a location within the same grid. A river is modeled as a single line along the centerline of the grid over the slope grid. The river is based on extra flow path between the grid lying over the actual river. The flow on the slope model simulates lateral inflows on the river based on two-dimensional modeling. Slope grids on the river are contained with two water depths: channel and slope. The flow interaction between the slope and river is estimated by different overflowing formulae using water level and levee height conditions. The RRI model uses the fifth-order Runge-Kutta method in the numerical scheme to apply diffusive wave routing to solve the two-dimensional 
equation. Flow rate equations in the governing equation of the RRI model, which is the mass balance equation based on continuity equation, are expressed as follows:

$$
\begin{aligned}
& \frac{\partial h}{\partial t}+\frac{\delta q_{x}}{\delta x}+\frac{\partial q_{y}}{\partial y}=r \\
& \frac{\partial q_{x}}{\partial t}=-g h \frac{\partial H}{\partial x}-\frac{\tau_{x}}{\rho} \\
& \frac{\partial q_{y}}{\partial t}=-g h \frac{\partial H}{\partial y}-\frac{\tau_{y}}{\rho}
\end{aligned}
$$

where $h$ is the water height in local surface; $t$ is the time step; $q_{x}$ and $q_{y}$ are the discharge per unit width in $x$ and $y$ directions; $r$ is rainfall intensity or lateral inflow; $H$ is the water depth from a datum; $\rho$ is the density of water; $g$ is gravitational acceleration; and $\tau_{x}$ and $\tau_{y}$ are shear stress in $x$ and $y$ directions.

Input datasets of the RRI model are four data types; rainfall product, Digital Elevation Model (DEM) presenting the topography from the Shuttle Radar Topographic Mission (SRTM) such as $500 \mathrm{~m}$ resolution. On the definition of the distributed hydrologic model with the RRI model, the used hydrologic parameters in the present study were recommended by the previous studies such as [7-12]. Those parameters have been based on calibration in previous RRI modeling studies. For the characteristics of the river channel, the resampled DEM was used for generating a flow direction to identify eight directions $\left(0^{\circ}, 45^{\circ}, 90^{\circ}\right.$, $135^{\circ}, 180^{\circ}, 225^{\circ}, 270^{\circ}$, and $315^{\circ}$ ), depending on the differential of the downstream elevation pixel $[9,10]$. The flow direction was used for counting numbers of the upstream pixels to identify a flow accumulate value to a specific pixel. In the present study, the flow accumulation was used for the estimation of the width and depth of the river channel followed by Sayama et al. (2012) [13].

\subsubsection{Environmental Fluid Dynamics Code Plus (EFDC+) Model}

The EFDC+ (Environmental Fluid Dynamics Code Plus) model was used for flood simulation in the present study [14]. This is an open-source code model that is available from the Github website [15]. The model solves the three-dimensional continuity, and free surface equations of motion developed initially by Hamrick [16]. The Mellor and Yamada level 2.5 turbulence closure scheme was implemented in the model [17]. The model has a flexible grid network structure capable of linking multiple tributaries to the main channel through grid linkage between upstream and downstream grid cells. The model has been successfully applied to a wide range of environmental studies [18-22]. The two-dimensional governing momentum equations of the EFDC model in the $x$-direction and $y$-direction can be simplified and written as follows.

$$
\begin{aligned}
& \frac{\partial(H u)}{\partial t}+\frac{\partial(H u u)}{\partial x}+\frac{\partial(H v u)}{\partial y}-\left(v \frac{\partial m_{y}}{\partial x}-u \frac{\partial m_{x}}{\partial y}\right) H v=-m_{y} H \frac{\partial(g \eta)}{\partial x}-m \frac{1}{\rho} C_{b} u \sqrt{\left(u^{2}+v^{2}\right)} \\
& \frac{\partial(H v)}{\partial t}+\frac{\partial(H u v)}{\partial x}+\frac{\partial(H v v)}{\partial y}+\left(v \frac{\partial m_{y}}{\partial x}-u \frac{\partial m_{x}}{\partial y}\right) H u=-m_{x} H \frac{\partial(g \eta)}{\partial y}-m \frac{1}{\rho} C_{b} v \sqrt{\left(u^{2}+v^{2}\right)}
\end{aligned}
$$

The continuity equation is:

$$
\frac{\partial(m \eta)}{\partial t}+\frac{\partial\left(m_{y} H u\right)}{\partial x}+\frac{\partial\left(m_{x} H v\right)}{\partial y}=0
$$

where $u, v$ are the horizontal velocity components in the $x$ and $y$ direction, respectively; $H$ is the water depth; $\eta$ is the free-water surface level; $m=m_{x} m_{y}$, where $m_{x}$ and $m_{y}$ are 
the transformation scale factors in horizontal coordinates; and $C_{b}$ is the bottom stress coefficient is given by

$$
C_{b}=\left(\frac{\kappa}{\ln \left(\frac{\Delta_{1}}{2 z_{0}}\right)-1}\right)^{2}
$$

where $\kappa=0.4$ is the von Karman constant; $\Delta_{1}$ is the thickness of the bottom layer; and $z_{0}$ is the dimensionless roughness height.

\subsection{Model Initial and Boundary Conditions}

Understanding the characteristics of floods constitutes one of the critical factors to reduce future flood disasters [23]. The present study investigated the detailed characteristics of riverbank overflow and rainfall-generated overland flow using both the RRI and EFDC+ models. The model grid configuration was a combination of several grid resolutions. The river channel used a very fine mesh resolution with an average grid cell of $3 \mathrm{~m}$ to better represent the river bed and river levee conditions. In contrast, the paddy field and town areas used a slightly coarser grid to optimize the simulation time (Figure 5). The model included 28,876 cells over an area of 77 ha.

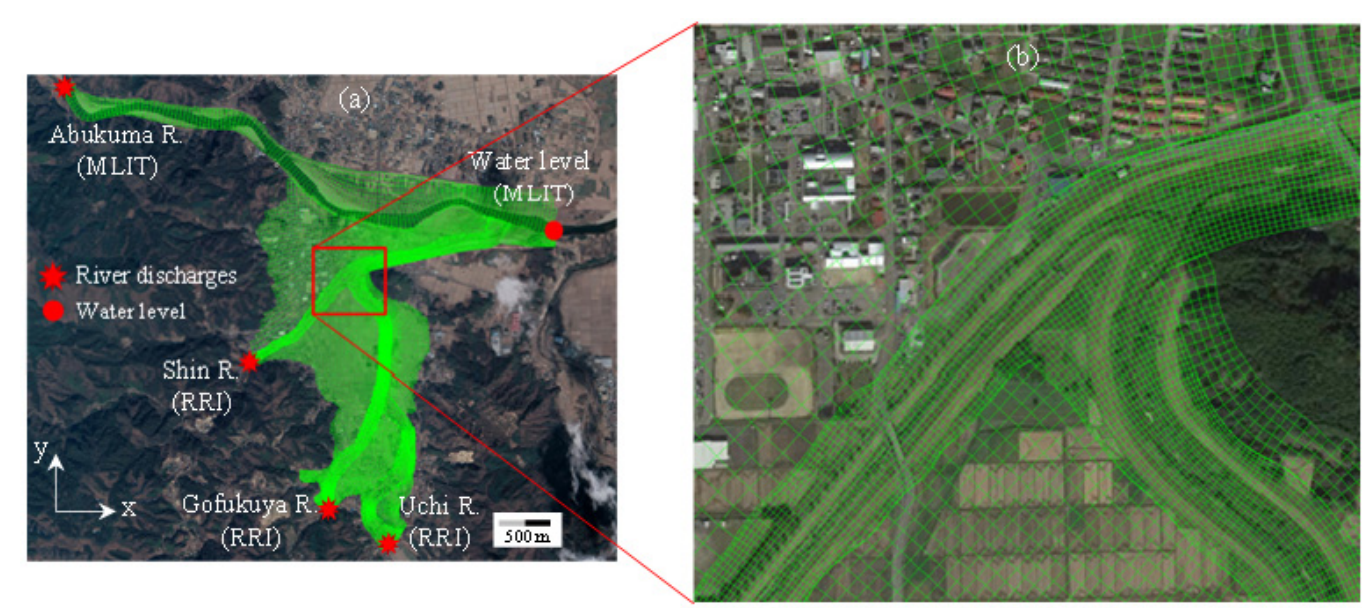

Figure 5. (a) EFDC+ model configuration and boundary condition locations, (b) Closer-view of model grid resolutions.

Figure 6 shows the time-series of river discharges and water levels at the boundary locations, as shown in Figure 5. The Abukuma River discharge and water level data during Typhoon Hagibis were collected from the MLIT, while the upstream river discharges of the Uchi River and the Gofukuya River were output results from the RRI model. In addition, the observed rainfall data at Hippo Station were used as the atmospheric boundary. Finally, the dimensionless roughness height was set based on the landcover surface types; for example, 0.03 for the river channel and 0.05 for the paddy field. 


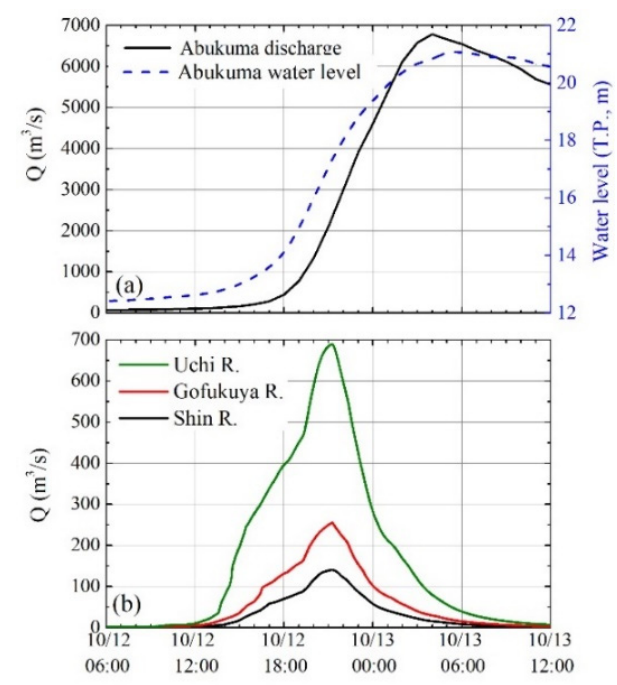

Figure 6. (a) Abukuma River discharge and water level from MLIT. (b) River discharge outputs from the rainfall-runoff-inundation (RRI) model for Uchi River, Gofukuya River, and Shin River at the boundary locations.

\subsection{Numerical Model Setup}

The above initial and boundary conditions were assigned in the model. The locations, width, and height of the levee breach points were set in the model based on the field observation results. The levee breach time was assessed based on the overflow water depth at the top of the levee and its duration, similar to the study by Suga et al. [24].

\subsection{Model Validation}

The measured water level data at Uchikawa Station (Figure 1b) and surveyed inundation water depth data in the Marumori Town were used to verify the numerical model. Although the Uchikawa Station was destroyed during the peak of the water level, it was valuable data for the model calibration and validation processes. The model performance was evaluated in terms of statistical variables such as root mean square error (RMSE) and Nash-Sutcliffe efficiency (NSE), which are defined by the following equations.

$$
\begin{gathered}
\text { RMSE }=\sqrt{\frac{\sum_{i=1}^{N}\left(O_{i}-P_{i}\right)^{2}}{N}} \\
\text { NSE }=1-\frac{\sum_{i=1}^{N}\left(O_{i}-P_{i}\right)^{2}}{\sum_{i=1}^{N}\left(O_{i}-\bar{O}_{i}\right)^{2}}
\end{gathered}
$$

where $N$ is the number of data points; $O_{i}$ and $P_{i}$ are, respectively, the observed data and model results; and $\bar{O}_{i}$ is the average value of measurement data.

Figure 7 shows the comparison results of the modeled and measured water level rise at Uchikawa Station. Although the simulated water level rise was slightly higher than the actual measured data, both showed good similarity, especially for the maximum height of the water level. The RMSE and NSE values were $0.682 \mathrm{~m}$ and 0.955 , respectively. These results indicate that our calibrated model predicted well for the water level rise in the river. Figure 7 also shows that the maximum water level from both the measured data and the simulated result was higher than the levee crest elevation, indicating the river's overflow and triggered many severe levee breaches in this area as observed. 


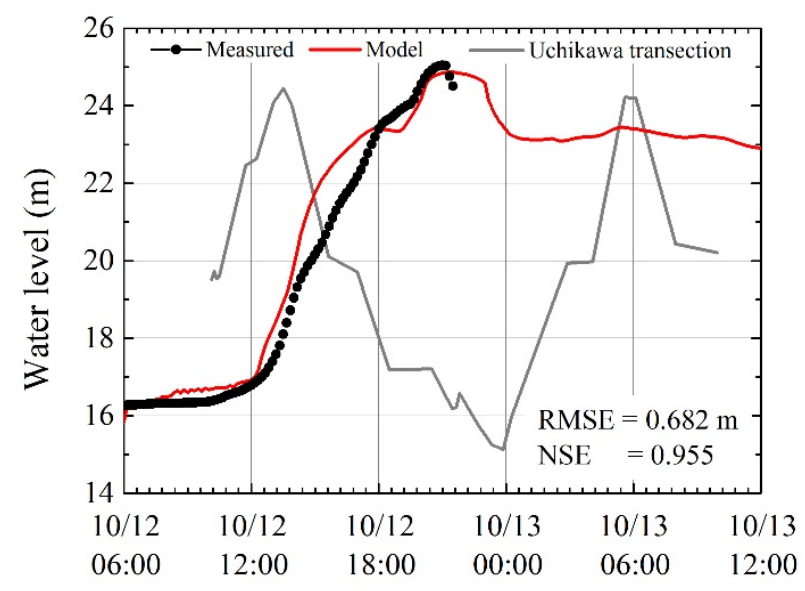

Figure 7. Time-series comparison result of the modeled and measured water level data at Uchikawa Station.

Figure 8 shows the model inundation map in the Marumori Town and flood marks' survey locations on 19 October 2019. Figure 9 is the comparison results of the model versus data for the inundation depth in the Marumori Town area. The small values of RMSE indicate that the model can successfully reproduce the inundation depth in Marumori Town.

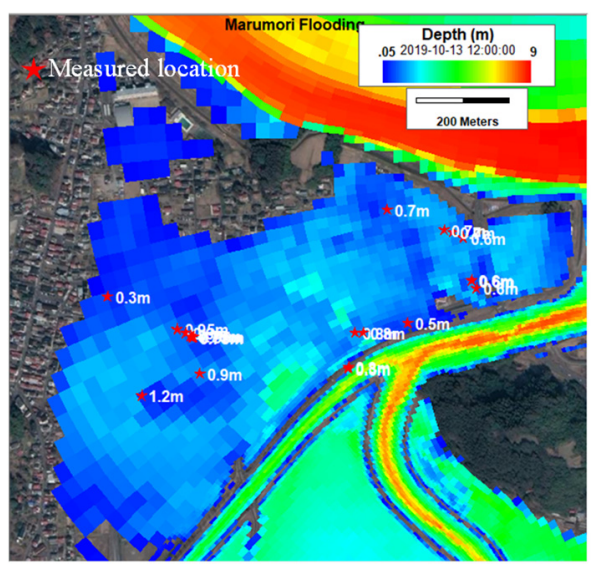

Figure 8. Model inundation map and flood marks' survey points at Marumori Town.

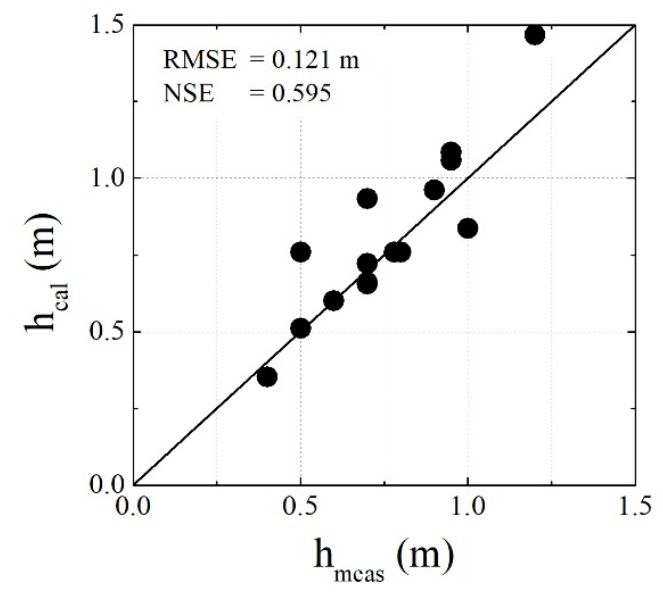

Figure 9. Comparison of modeled versus measured inundation depths. 
Overall, based on these comparison results, we can conclude that the EFDC+ flood model satisfactorily captured the time variation of water level rise and inundation depths. Therefore, the EFDC+ model results' accuracy is sufficient for further discussing the flood characteristics during Typhoon Hagibis in the Marumori area.

\section{Results and Discussion}

\subsection{Field Survey Result}

\subsubsection{Field Survey Result of Flood Damage in Marumori Town}

On 13 October 2019, we conducted a field survey of the situation in the center of Marumori Town and the riverbank's damages along the tributaries one day after the typhoon. The center of the town is located in a triangular area, extending east to west between the mainstream Abukuma River and the Shin River's left-side, as shown in Figure 1. Marumori Town experienced flood disasters with a cumulated rainfall exceeding $400 \mathrm{~mm}$ during Typhoon No. 10 on 5 August 1986 [25]. However, the flood-induced disaster by Typhoon Hagibis was the most severe. Immediately after the typhoon, the municipal government believed that the flooding in the town was caused by the Abukuma riverbank's breach and water overflow from the left side of the Shin River. However, according to our observation results, no breach happened on the Abukuma riverbank and the Shin River's left riverbank. The town's floodwaters were mainly from the direct intensive rainfall, and water flowed from a nearby mountainside. In addition, the massive amount of floodwater to the city far exceeded the capacity of the drainage pumps to the Shin River (Figure 10). Therefore, the inundation depth was high and exceeded $3 \mathrm{~m}$ in some areas.

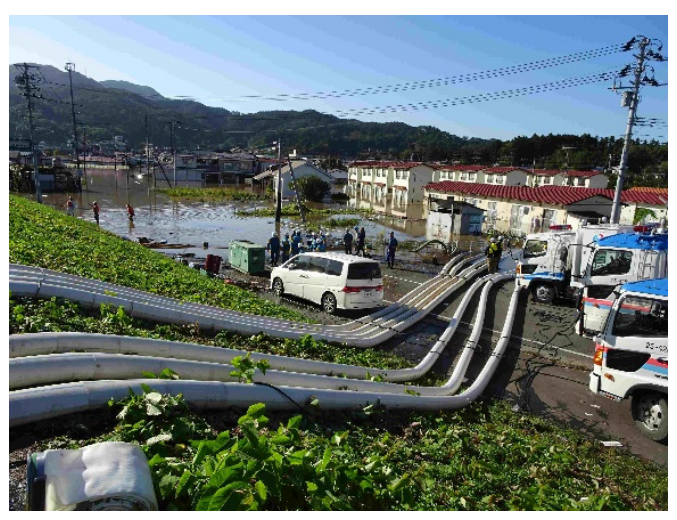

Figure 10. Pumping system for the drainage of the inundation water to the Shin River (photo was taken on 13 October 2019).

\subsubsection{Field Survey Result of Levee Damages}

A detailed survey by helicopter was carried out one day after the flood disaster by MLIT. Figure 11 is a photo taken from a helicopter. There were 18 levee breaching locations, of which 10 were in the Uchi River, four in the Shin River, and four in the Gofukuya River. There were 10 major levee breach positions, as shown in Figure 11. Figure 12 shows a closer-view photo of the breached portions taken in two surveys on 13 October and 19 October 2019. Based on the level of levee damage, the present study categorized the damage into three different levels as shown in Figure 13: (1) Complete damage level, (2) partial damage level, and (3) no-damage. 


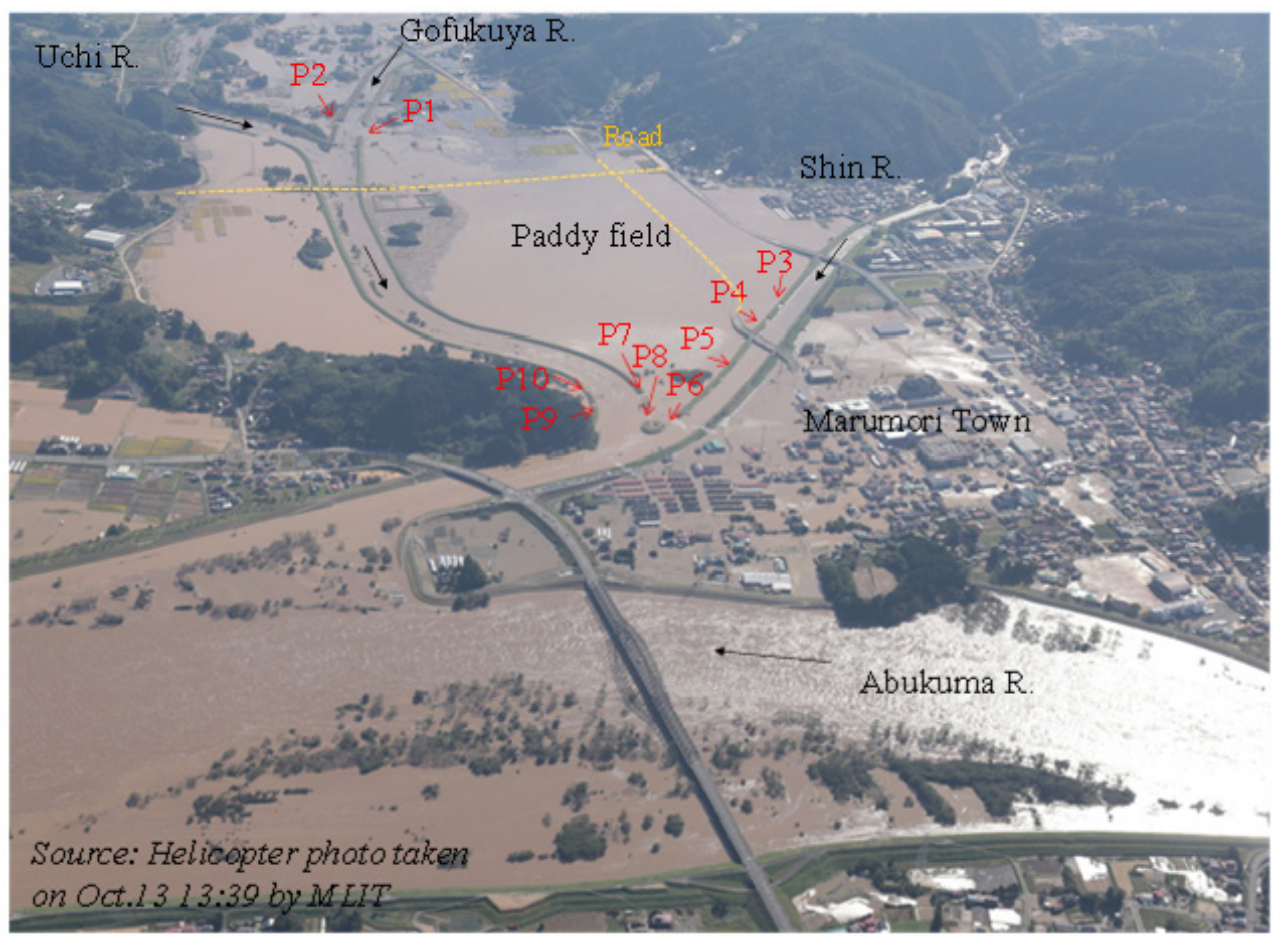

Figure 11. Helicopter photo of the Marumori area on October 13 by MLIT and locations of the levee breaches.
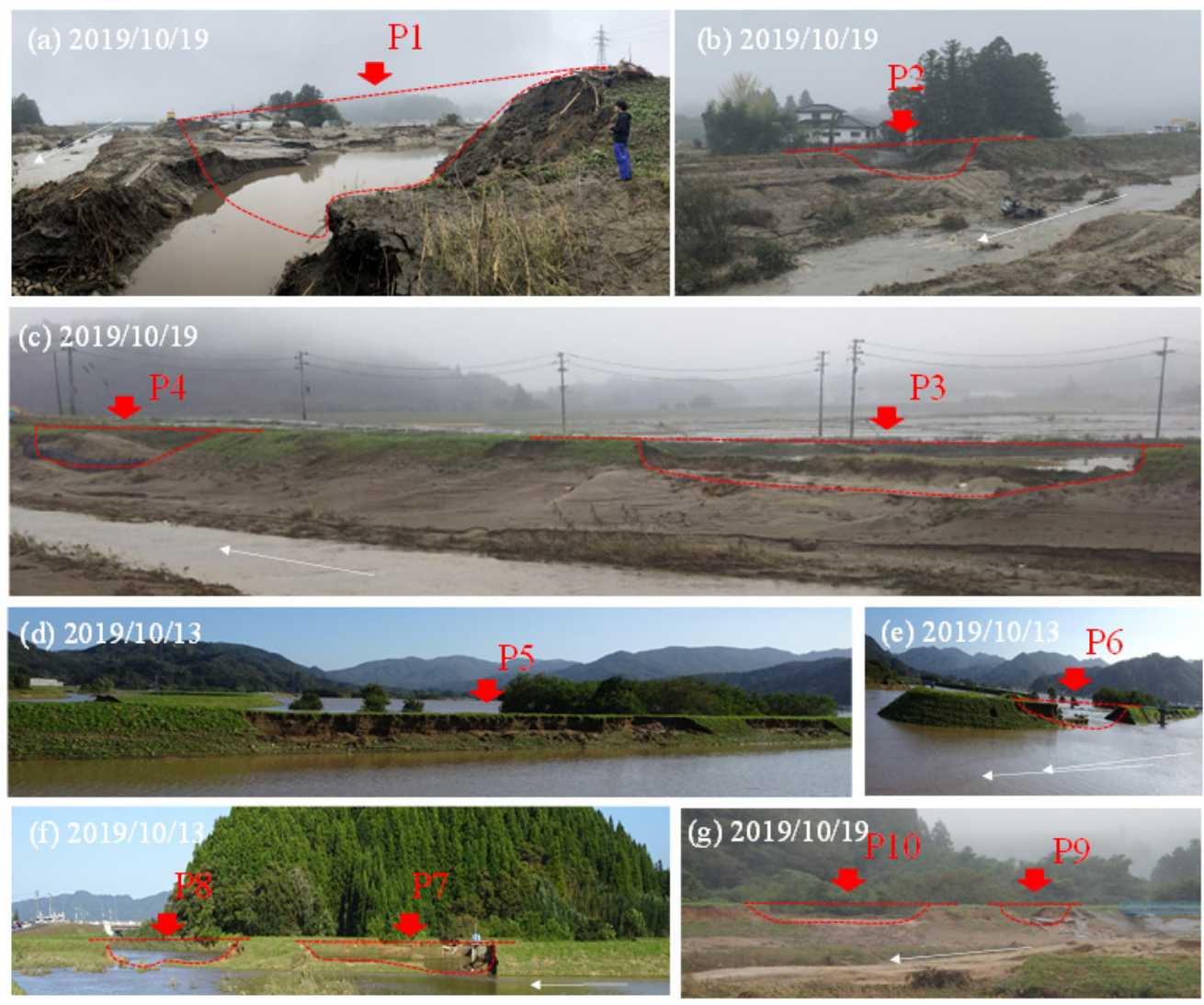

Figure 12. Post-event photographs of levee breaches at corresponding locations from the P1 to P10 in Figure 11 along the Uchi, Gofukuya, and Shin Rivers. 

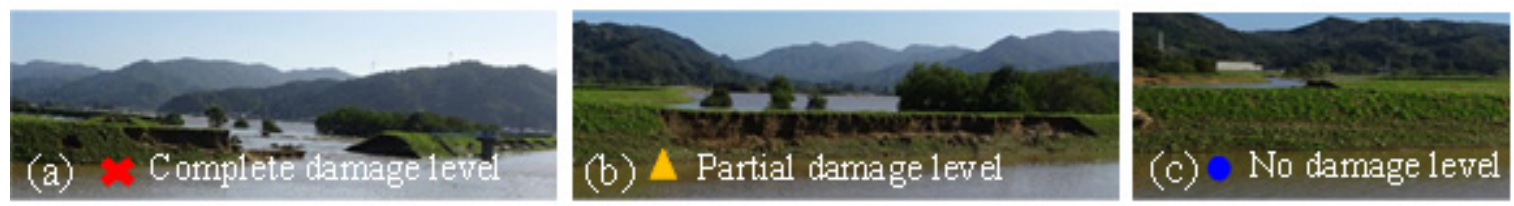

Figure 13. Classification of levee damage level (a) Complete damage level, (b) Partial damage level, (c) No damage level.

According to the field survey results, the levee breached position in the Gofukuya River (P1) was the most severe location (Figure 12a). The levee was destroyed entirely for more than $60 \mathrm{~m}$, causing a large amount of water from the Gofukuya and Uchi Rivers to flow into the paddy field area. Many levee portions were breached at the Uchi River and Gogukuya River's confluence due to the river water level rise that surpassed the embankment crest (Figure 7).

Figure 12a-d shows photographs taken at the levee breaching positions along the Shin River's right bank. It can be seen that complete damage positions (P3, P4, P6) usually took place at the constricted corners between two river embankments or the riverbank and road (Figure 14). It is important to note that partial levee damage was observed along $220 \mathrm{~m}$ on the Shin River's rightbank at the P5 position (Figure 12d). The levee's scouring on the riverside suggested that the overflow direction was from the paddy field to the Shin River channel. Kawagoe [26] also reported similar levee breaching mechanisms at six different places in Fukushima Prefecture during Typhoon Hagibis. The water overflow from the land area resulting in levee damage was also reported during heavy rainfall in Hokkaido in August 2016, according to Ishida et al. [27].

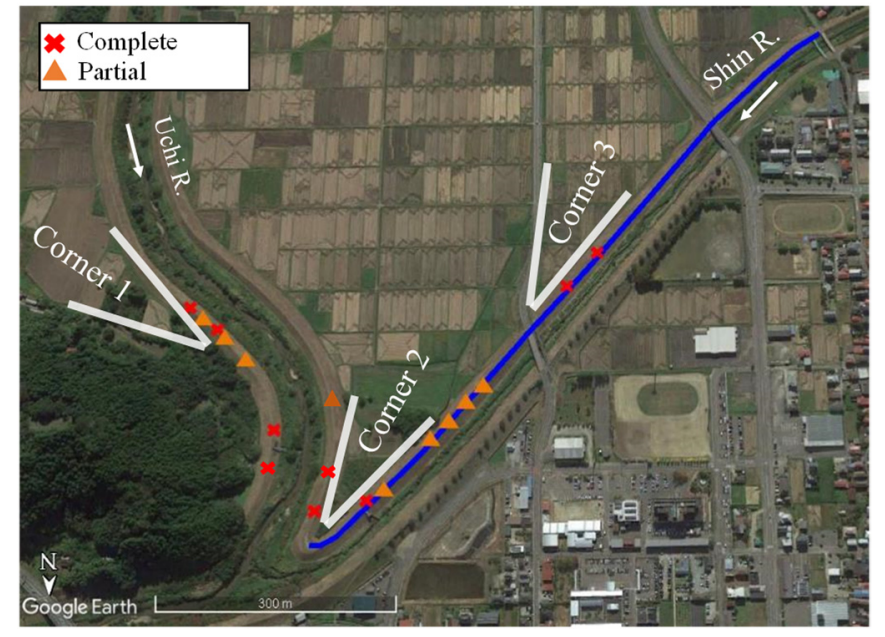

Figure 14. Levee damages at the constricted corners.

Figure 12f,g shows the complete levee damage positions downstream of the Uchi River (P7 to P10). The breaching mechanisms of these locations were similar to the P6 position. However, the eyewitness information was not obtained because the Marumori flood occurred at night time. Therefore, it is necessary to clarify the flood characteristics and breaching mechanisms using the $2 \mathrm{D}$ version of the EFDC+ numerical model in the next section.

\subsection{Numerical Simulation of Flood Propagation in the Marumori Area \\ 3.2.1. Numerical Simulation of the Floodwater Propagation Process}

Figure 15 shows a series of snapshots from the numerical simulation results of the flood propagation process. In this simulation, a constant $100 \mathrm{mg} / \mathrm{l}$ of dye was assigned to the inflow boundaries of three tributaries to track floodwater movement over land areas. 
Therefore, the warm color indicates the incoming floodwater, and the cold color is the rainfall water.
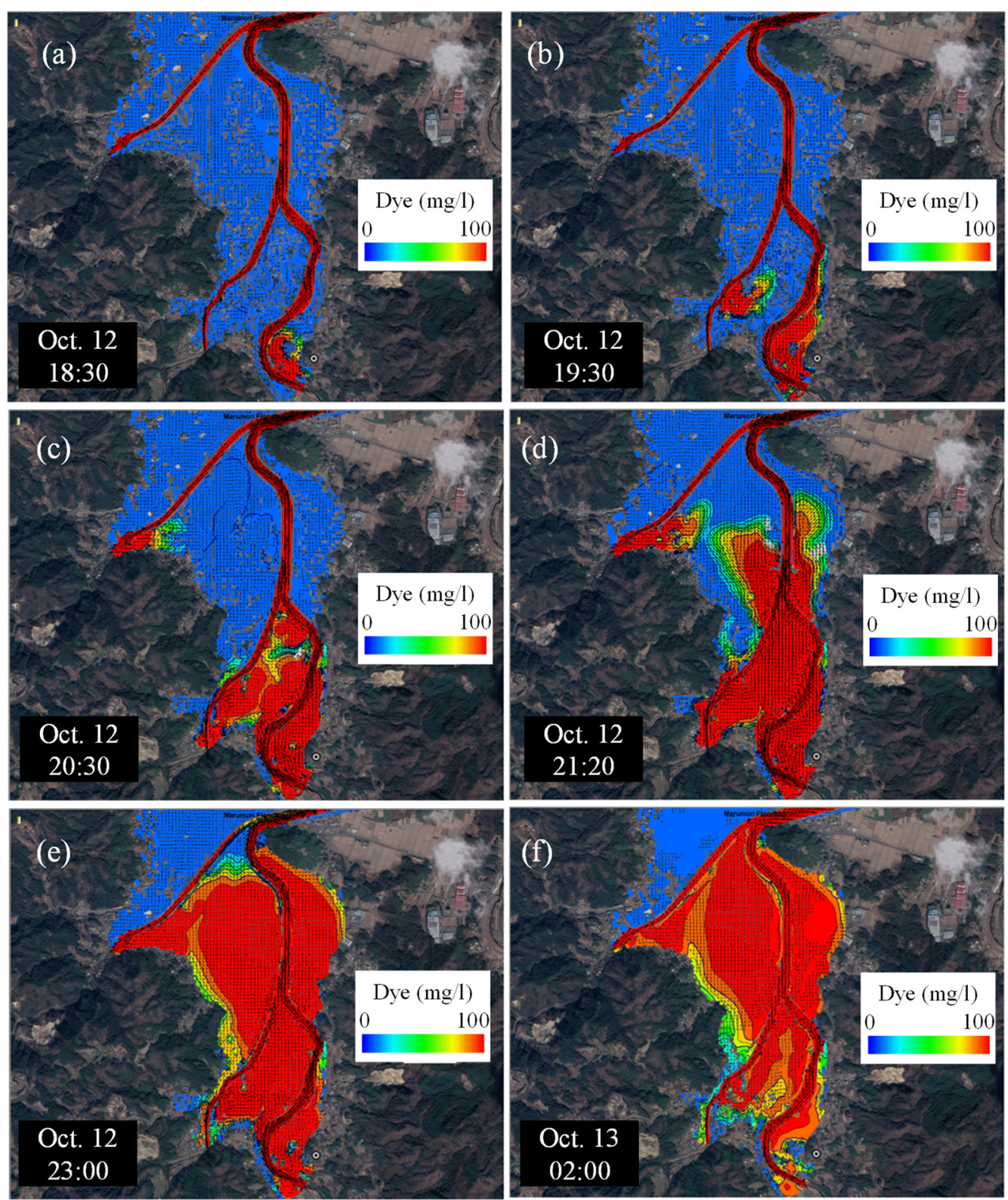

Figure 15. Simulation results of the river overflow and flood propagation in the Marumori area; where $(\mathbf{a}-\mathbf{f})$ are the model snapshots at different times.

Intensive rainfall started from 10:00 on 12 October 2019, making the river flow increase gradually. The initial overflow occurred in the upper part of the Uchi River's right riverbank at around 18:30, causing flooding in extensive areas, as seen in Figure 15a. The initial overflow on the right riverbank of the Gofukuya River occurred at about 19:30 (Figure 15b), while it happened around 20:10 on the right riverbank of the Shin River (Figure 15c). Hence, floodwaters from rivers were extended into the land areas between the Uchi River and Gofukuya River, causing severe flooding and water level rise. At 21:20, the overflow occurred on both sides of the riverbanks at the Uchi River and Gofukuya River's confluence in Figure 15d. The overflow mechanism at the junction was due to the flow intensity at a constricted corner, as discussed in the previous section. After the levee breached, the floodwater from the breaching portion increased and flowed into the paddy field land area, causing water level rise at the downstream corners. Hence, overflow from the paddy 
field to the river caused levee damages in the downstream positions from P3 to P10 in Figure 11, as observed in the field surveys (Figure 15e,f). The numerical simulation results also indicated that overflow was not seen on the left riverbank of the Shin River during the flood event.

In conclusion, the detailed flood characteristics in Marumori Town were successfully reproduced by the $2 \mathrm{D}$ version of the EFDC + numerical model. The obtained model results agreed well with the lessons learned from the field observation results after the flood disaster.

\subsubsection{Levee Breaching Criterion}

In order to investigate the flow characteristics that caused the levee breaching, the maximum overflow water depth on the levee crest was extracted from the model results. Figure 16a shows where the extracting lines $x_{1}$ and $x_{2}$ were set for the Shin River and Uchi River, where the star symbol indicates the origin of coordinates. Figure $16 \mathrm{~b}-\mathrm{d}$ respectively shows the longitudinal variation of the maximum overflow depth $\left(h_{0}\right)$ on the Shin River's right-bank, Uchi River's right-bank, and Uchi River's left-bank. In these figures, the location and levee damage levels, as observed in Figure 14, are also shown. As shown in Figure 16, the higher overflow depth has occurred in the constricted corners 1 to 3. In addition, the complete levee damage has corresponded well to the location of enormous overflow depth.
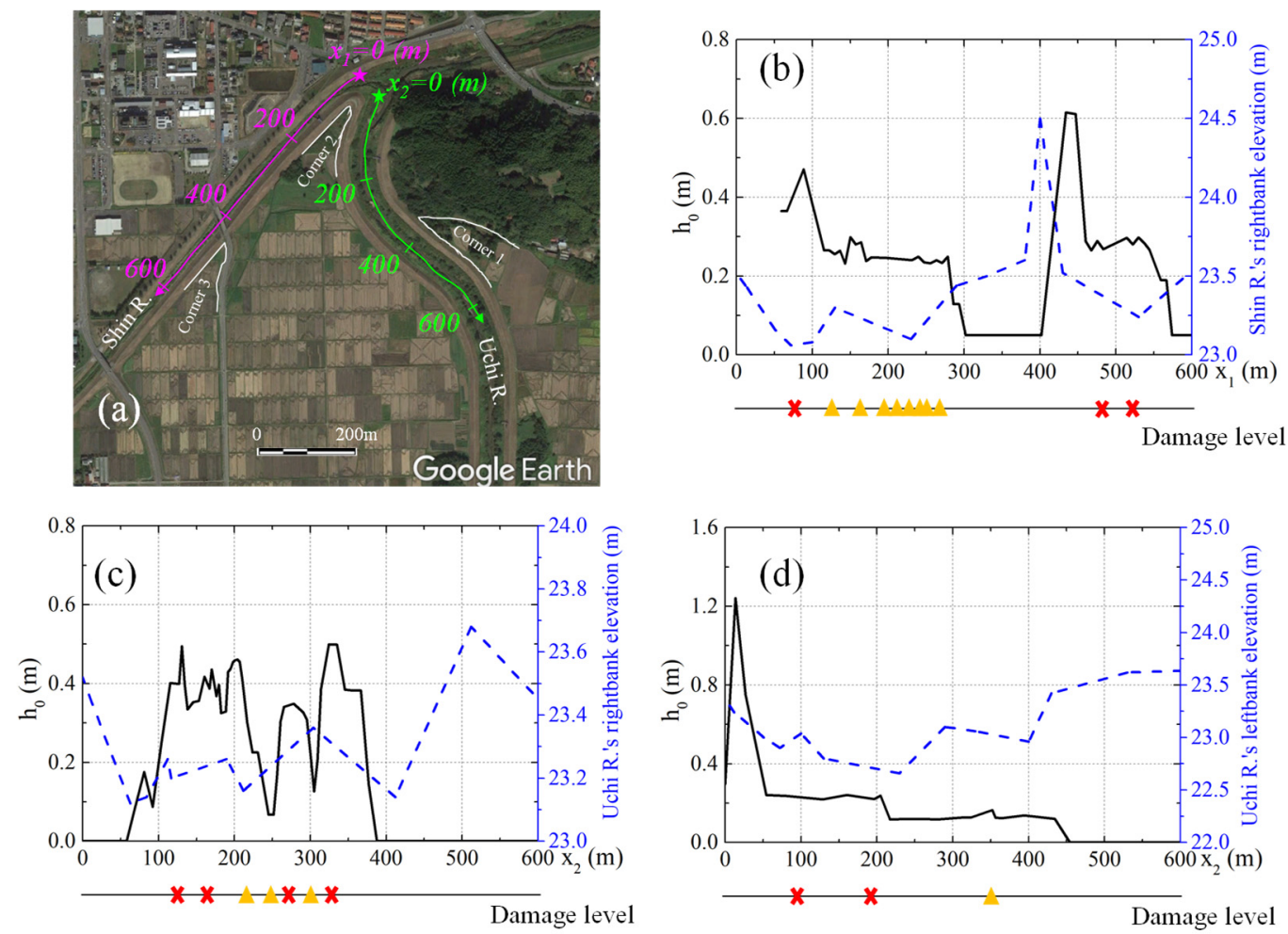

Figure 16. (a) Extracting line along the Shin River and Uchi River, (b) maximum overflow depth on the Shin River's right-bank, (c) Uchi River's right-bank, (d) Uchi River's left-bank.

According to Suga et al. [18], the levee breaching criterion can be defined as a function of the maximum overflow depth $\left(h_{0}\right)$ and its overflow duration $\left(t_{0}\right)$. Based on the simulation results, these parameters can be extracted at all damaged locations, as shown in Figure 17. From this analyzed result, it can be seen that complete levee damage is more likely to occur when the overflow depth reaches $0.4 \mathrm{~m}$ and remains for a duration of $200 \mathrm{~min}$. Based 
on the collected data, Suga et al. [24] proposed a criterion for the complete levee breaching as follows:

$$
h_{0}=\frac{110}{t_{0}}
$$

where the unit of maximum overflow depth, $h_{0}$, is in meters and the overflow duration, $t_{0}$, is in minutes.

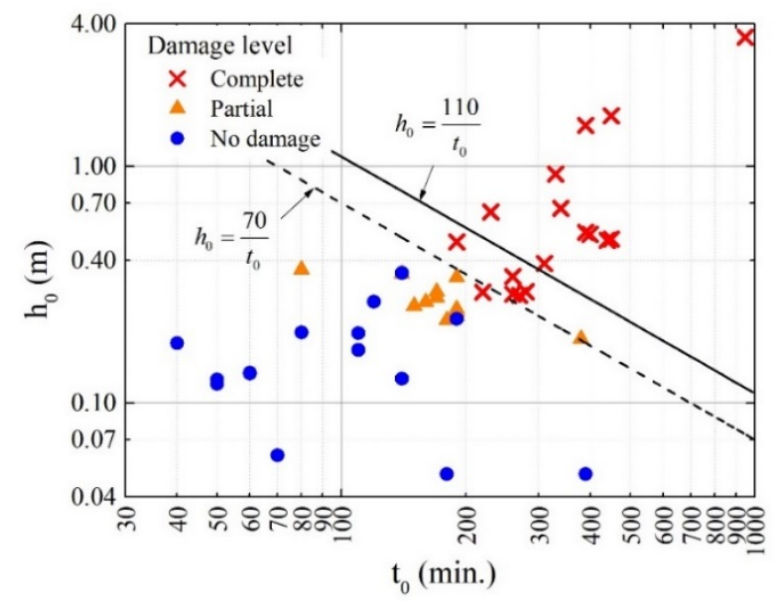

Figure 17. Simulated results of the overflow depth $\left(h_{0}\right)$ and overflow duration $\left(t_{0}\right)$ at the damage locations.

However, based on the present investigation, the new criterion to define the complete levee damage level for the Marumori case is the following equation.

$$
h_{0}=\frac{70}{t_{0}}
$$

Figure 17 plots the comparison result of these two equations. The present breaching criterion is somewhat lower than Suga's criterion. However, the differences might be due to the levee materials and levee body shape. Suga's criterion was derived based on survey data in various levee materials such as soil levee and asphalt-covered on the top of levees, whereas the levee system in the Marumori area was made of soil and had no pavements.

\subsubsection{Summary of Levee Breaching Mechanisms in the Marumori Area}

As discussed in the above sections, there were two main levee breaching mechanisms in the Marumori area during the October 2019 flood disaster. The first mechanism was due to the river water level rise at the river confluence, causing overflow on the levee crest that resulted in a partial or complete damage level, as shown in Figure 18. This levee failure mechanism occurred at the confluence area between the Uchi River and Gofukuya River. Furthermore, other mechanisms at a river confluence that might affect the levee breaching include the generation of coherent structures and modification of the water surface [28], hydraulic jumps and their instability [29], and reciprocal adjustment of flow, sediment, and morphodynamics at a confluence near coastal areas [30]. 


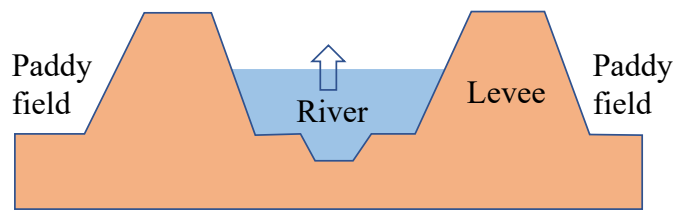

(a) River water level rise

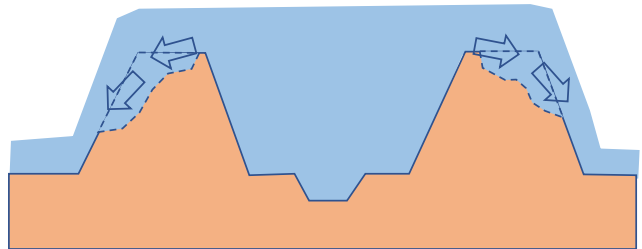

(b) Partial levee damage due to overflow from river

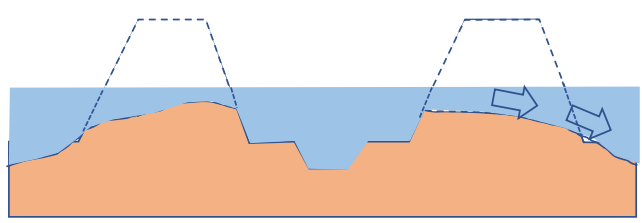

(c) Complete levee damage

Figure 18. Breaching mechanism of the upstream levee location: (a) River water level rise, (b) Partial levee damage due to overflow from river, (c) Complete levee damage.

The second levee breaching mechanism was a consequence of the occurrence of the first breach. A large amount of floodwater through the upstream levee breaching locations flowed into the paddy field areas, which concentrated at the constricted areas downstream, causing the overflow from the paddy to the river shown in Figure 19. The levee's partial or complete damage depends mainly on the maximum overflow depth, overflow duration, and levee materials.

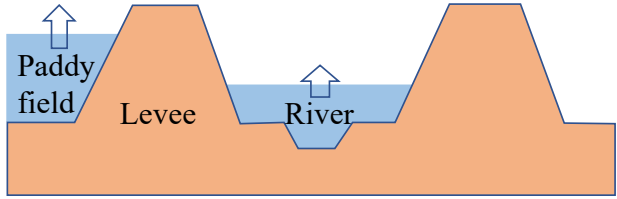

(a) Paddy field water level rise

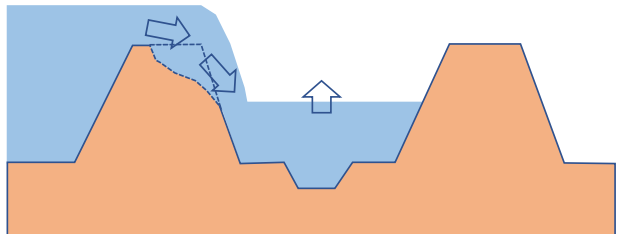

(b) Partial levee damage due to overflow from the paddy field

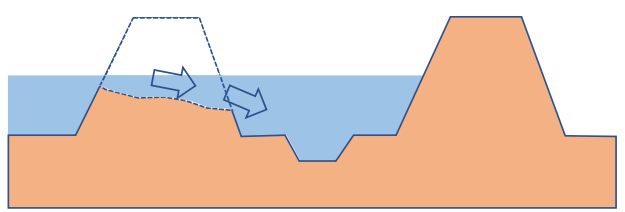

(c) Complete levee damage

Figure 19. Breaching mechanism of the downstream levee locations: (a) Paddy field water level rise, (b) Partial Levee damage due to overflow from the paddy field, (c) Complete levee damage. 
In addition to these two mechanisms, we observed that the effects of stagnant wooden debris at bridge locations also caused water level rise and overflowed the riverbanks. Understanding the Marumori area's flood characteristics is crucial in the prevention and mitigation of future flood disasters.

\subsubsection{Effect of the Backwater Phenomenon}

Backwater is a phenomenon when the mainstream river water level rises and blocks water flow from its tributaries. This backwater phenomenon occurred in many places and caused levee breaches in Fukushima Prefecture [29]. However, according to the water level measurement data during the Typhoon Hagibis flooding, the phase difference between the peak water level at Marumori Station in the Abukuma River and at the Uchikawa Station in the Uchi River was about $8 \mathrm{~h}$ (Figure 20). Fortunately, this phase lag was sufficient for the tributaries' floodwaters to discharge into the Abukuma River before the Abukuma River water level reached its peak. Therefore, the backwater effects were significantly reduced during the 2019 flood event. Nevertheless, according to the historical flood data in the Marumori area, the phase lag differences could vary from 4 to $9 \mathrm{~h}$. Hence, to evaluate future possible backwater effects, a series of hypothetical scenarios with a smaller phase lag was conducted, as shown in Table 1. Scenario 1 is the actual conditions of the Hagibis flood. The other scenarios were set up by adjusting the time-series of the Abukuma River's river discharge and the water level with a 1-h time interval.

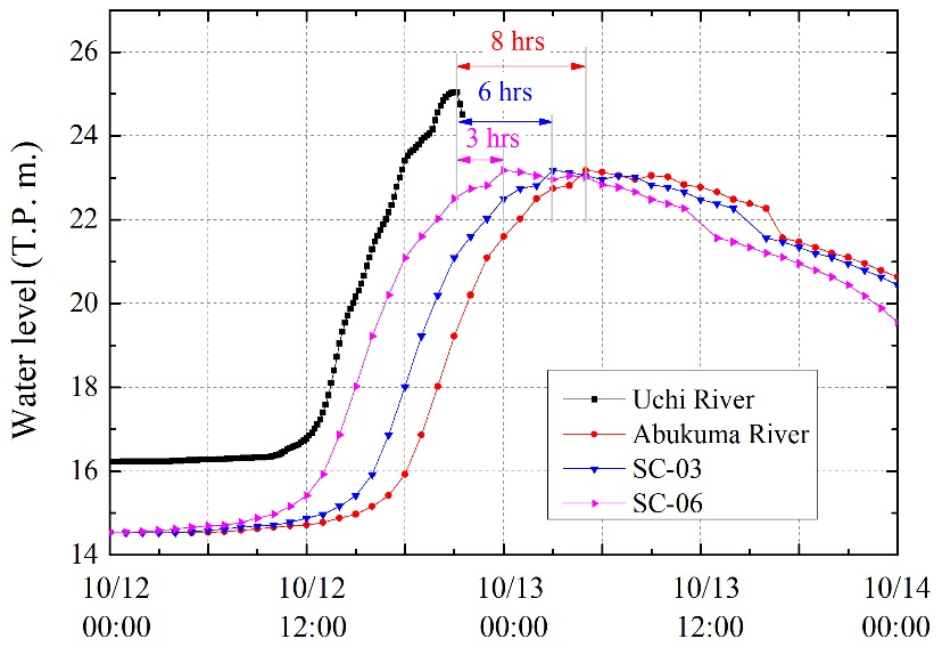

Figure 20. Phase lag difference of model scenarios.

Table 1. Summary of model scenarios.

\begin{tabular}{cccc}
\hline Scenarios & $\begin{array}{c}\text { Occurrence Time of } \\
\text { Maximum Water Level } \\
\text { in the Uchikawa River }\end{array}$ & $\begin{array}{c}\text { Time Occurrence of } \\
\text { Maximum Water Level } \\
\text { in the Abukuma River }\end{array}$ & $\begin{array}{c}\text { Phase Lag } \\
\text { (h) }\end{array}$ \\
\hline SC-01 (Actual & $12 / 10 / 202021: 00$ & $13 / 10 / 20205: 00$ & 8 \\
Condition) & $12 / 10 / 202021: 00$ & $13 / 10 / 20204: 00$ & 7 \\
SC-02 & $12 / 10 / 202021: 00$ & $13 / 10 / 20203: 00$ & 6 \\
SC-03 & $12 / 10 / 202021: 00$ & $13 / 10 / 20202: 00$ & 5 \\
SC-04 & $12 / 10 / 202021: 00$ & $13 / 10 / 20201: 00$ & 4 \\
SC-05 & $12 / 10 / 202021: 00$ & $13 / 10 / 20200: 00$ & 3 \\
SC-06 & &
\end{tabular}

The analyzed results of the maximum overflow depth and overflow duration at nine points along the Shin River's left riverbank in Figure 21 are shown in Figure 22. A significant overflow from the river to Marumori Town appears as the phase lag of $5 \mathrm{~h}$. The smaller the phase lag, the higher the overflow depth obtained. According to the new 
levee breach criterion in the present study, partial and complete levee breaches on the left riverbank of Shin River can be observed when the phase lag is from $3 \mathrm{~h}$ to $4 \mathrm{~h}$.

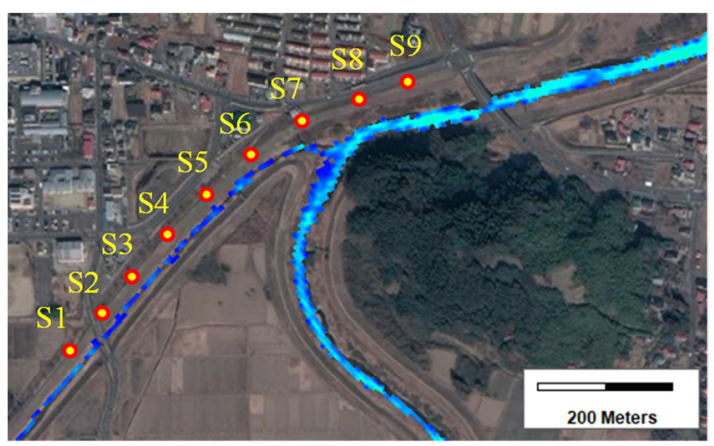

Figure 21. Extracted points on the left riverbank of the Shin River.

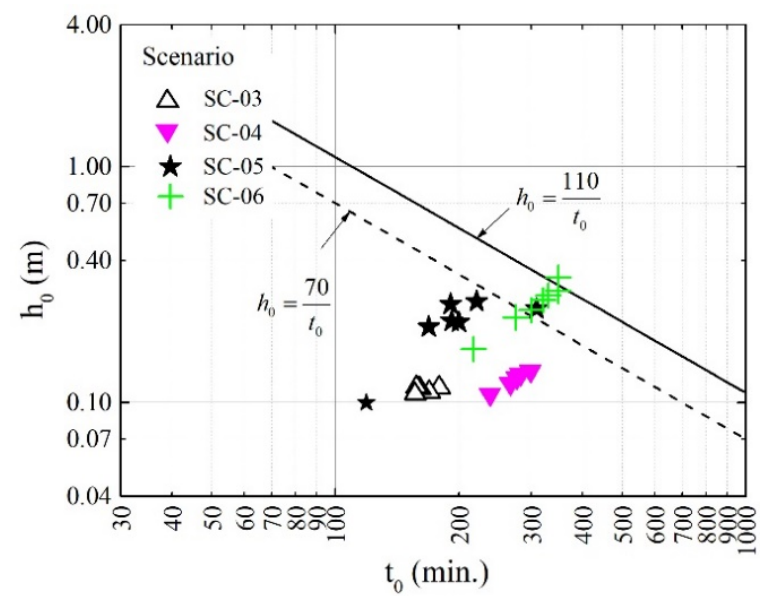

Figure 22. Comparison of levee damage level in different scenarios.

\section{Conclusions}

The present study investigated the detailed flood characteristics at Marumori Town using both field observation and numerical simulations. The water level rises at the constriction areas of the tributaries' junction or the river embankment intersection that caused overflow were the main mechanisms for the levee breaches. The river's floodwater throughout the upstream levee breach locations could cause an overflow on the riverbank in the downstream area. Based on the numerical simulation results, a new levee breach criterion was developed in terms of the overflow depth and its duration on the river embankment. It is more likely that a soil bank levee will be completely damaged when an overflow depth of $0.4 \mathrm{~m}$ is maintained for about $3 \mathrm{~h}$. In addition, a sensitivity analysis of the backwater effects was also performed in this study. The overflow from the Shin River to Marumori Town might occur if the phase lag between the Uchi River water level and Abukuma water level is less than $6 \mathrm{~h}$. The present study outcomes provide useful information to understand how the river embankment of the tributaries is vulnerable to the water level rise and to support the river authorities to prepare better mitigation or evacuation plans for future flood disasters.

Author Contributions: N.X.T. and H.T. were responsible for the conceptualization, investigation, and wrote the original draft of the manuscript; G.A. and Y.O. were responsible for the numerical model simulation, model verification, and analysis; K.P. was responsible for the rainfall-runoff-inundation model (RRI model). All authors have read and agreed to the published version of the manuscript.

Funding: This research was funded by the KAKENHI research fund (no. 19K24678). 
Institutional Review Board Statement: Not applicable.

Informed Consent Statement: Not applicable.

Data Availability Statement: Data sets are contained within the article. Further data and materials requests should be addressed to nguyen.xuan.tinh.c5@tohoku.ac.jp (N.X.T.) or hitoshi.tanaka.b7@tohoku.ac.jp (H.T.).

Acknowledgments: The field survey of this investigation was carried out as an activity of the Japan Society of Civil Engineers, Hydraulic Engineering Committee, and Tohoku Scientific Joint Survey Team (Tohoku Group) for the 2019 Hagibis Typhoon disaster. Moreover, the river bed data were obtained from the Miyagi Rivers Division Office. Furthermore, this research was funded by KAKENHI (no. 19K24678). We would like to express our gratitude and thank all who supported us in this research.

Conflicts of Interest: The authors declare no conflict of interest.

\section{References}

1. JMA (Japan Meteorological Agency). Climatology of Tropical Cyclones. Available online: https://www.jma.go.jp/jma/jma-eng/ jma-center/rsmc-hp-pub-eg/climatology.html (accessed on 15 September 2020).

2. JWF (Japan Water Forum). 1959 Super Typhoon Vera: 50 Year Retrospective. Risk Management Solutions (RMS). 2009. Available online: https:/ / forms2.rms.com/rs/729-DJX-565/images/tc_1959_super_typhoon_vera.pdf (accessed on 15 October 2020).

3. Shimozono, T.; Tajima, Y.; Kumagai, K.; Arikawa, T.; Oda, Y.; Shigihara, Y.; Mori, N.; Suzuki, T. Coastal impacts of super typhoon Hagibis on Greater Tokyo and Shizuoka areas, Japan. Coast. Eng. J. 2020, 1-17. [CrossRef]

4. NHK (NHK WORLD-JAPAN). Typhoon Hagibis Aftermath. 2019. Available online: https://www3.nhk.or.jp/nhkworld/en/ news/special/typhoon201919/?fbclid=IwAR2xYfyP7MNiS13EWN2VuTe11Wg6O9a-ma2AxZOgWeH_sO-9nsDLSrXoK0E (accessed on 1 October 2020).

5. GSI (The Geospatial Information Authority of Japan). Available online: https://fgd.gsi.go.jp/download/ (accessed on 15 February 2020).

6. Sayama, T.; Fukami, K.; Tanaka, S.; Takeuchi, K. Rainfall-runoff-inundation analysis for flood risk assessment at the regional scale. In Proceedings of the Fifth Conference of Asia Pacific Association of Hydrology and Water Resources (APHW), Hanoi, Vietnam, 8-10 November 2010; pp. 568-576.

7. Chow, V.T.; Maidment, D.R.; Mays, L.W. Applied Hydrology, 6th ed.; McGraw Hill International Editions: New York, NY, USA, 1988.

8. Sriariyawat, A.; Pakoksung, K.; Sayama, T.; Tanaka, S.; Koontanakulvong, S. Approach to estimate the flood damage in sukhothai province using flood simulation. J. Disas. Res. 2013, 8, 406-414. [CrossRef]

9. Jenson, S.K.; Domingue, J.O. Extracting topographic structures from digital elevation data from geographic information system analysis. Photogramm. Eng. Remote Sens. 1988, 54, 1593-1600.

10. Martz, L.W.; Jong, D.E. CATCH: A Fortran program for measuring catchment area from digital elevation models. Comp. Geosci. 1988, 25, 835-844. [CrossRef]

11. Pakoksung, K.; Takagi, M. Effect of satellite based rainfall products on river basin responses of runoff simulation on flood event. Model. Earth Syst. Environ. 2016, 2, 143. [CrossRef]

12. Pakoksung, K.; Takagi, M. Effect of DEM sources on distributed hydrological model to results of runoff and inundation area. Model. Earth Syst. Environ. 2020. [CrossRef]

13. Sayama, T.; Ozawa, G.; Kawakami, T.; Nabesaka, S.; Fukami, K. Rainfall-runoff-inundation analysis of the 2010 pakistan flood in the kabul river basin. Hydrol. Sci. J. 2012, 57, 298-312. [CrossRef]

14. DSI. EFDC+ Theory Version 10.2; DSI LLC: Edmonds, WA, USA, 2020; Available online: https: / /www.eemodelingsystem.com/ efdcplus-theory (accessed on 1 October 2020).

15. EFDC+ (Environmental Fluid Dynamics Code Plus). Available online: https://github.com/dsi-llc/EFDCPlus (accessed on 15 May 2019).

16. Hamrick, J.M. A Three-Dimensional Environmental Fluid Dynamics Computer Code: Theoretical and Computational Aspects; Special Report in Applied Marine Science and Ocean Engineering. No. 317; Virginia Institute of Marine Science: Gloucester Point, VA, USA, 1992; 63p.

17. Mellor, G.L.; Yamada, T. Development of a turbulence closure model for geophysical fluid problems. Rev. Geophys. Space Phys. 1982, 20, 851-875. [CrossRef]

18. Zhou, J.; Falconer, R.A.; Lin, B. Refinements to the EFDC model for predicting the hydro-environmental impacts of a barrage across the Severn Estuary. Renew. Energy 2014, 62, 490-505. [CrossRef]

19. Gong, W.; Shen, J. The response of salt intrusion to changes in river discharge and tidal mixing during the dry season in the Modaomen Estuary, China. Conti. Shelf Res. 2011, 31, 769-788. [CrossRef]

20. Yoon, B.; Woo, S.B. The along-channel salinity distribution and its response to river discharge in tidally-dominated Han River Estuary, South Korea. Procedia Eng. 2015, 116, 763-770. [CrossRef] 
21. Liu, C.J.; Yu, M.H.; Jia, L.W.; Cai, H.Y.; Chen, X.Q. Impacts of physical alterations on salt transport during the dry season in the Modaomen Estuary, Pearl River Delta, China. Estuar. Coast. Shelf Sci. 2019, 227, 106345. [CrossRef]

22. Gao, Q.; He, G.; Fang, H.; Bai, S.; Huang, L. Numerical simulation of water age and its potential effects on the water quality in Xiangxi Bay of three gorges reservoir. J. Hydrol. 2018, 566, 484-499. [CrossRef]

23. UNISDR (United Nations International Strategy for Disaster Reduction). GAR 2015 Making Development Sustainable: The Future of Disaster Risk Management; UNISDR: Geneva, Switzerland, 2015.

24. Suga, K.; Ishikawa, T.; Kasai, T. Levee breach characteristics due to overflow water. JSCE Proc. (Hydraulic Eng.) 1981, 3, 355-360. (In Japanese)

25. Shuto, N. Inundation of the Yoshida River, 1986 Survey on Disasters in the Kanto and Tohoku Regions Caused by Typhoon No. 10; Ministry of Education Research Fund Natural Disaster Research Report 1987; JSCE: Tokyo, Japan, 1987; Chapter 12; pp. 112-120. (In Japanese)

26. Kawagoe, S. Typhoon No. 19 in the First Year of Reiwa, Damage and Consideration in Fukushima Prefecture; Summary of Technical Research Presentations of the Tohoku Branch of the Japan Society of Civil Engineers; JSCE: Tokyo, Japan, 2020. (In Japanese)

27. Ishida, Y.; Kuka, T.; Shimizu, Y. Survey and factor verification of flood damage in the Sorachigawa Ikutora area due to heavy rain in Hokkaido in August 2016. JSCE Proc. B1 (Water Eng.) 2017, 73, I_1429-I_1434. (In Japanese) [CrossRef]

28. Bilal, A.; Xie, Q.; Zhai, Y. Flow, sediment, and morpho-dynamics of river confluence in tidal and non-tidal environments. J. Mar. Sci. Eng. 2020, 8, 591. [CrossRef]

29. Biron, P.M.; Richer, A.; Kirkbride, A.D.; Roy, A.G.; Han, S. Spatial patterns of water surface topography at a river confluence. Earth Surf. Process. Landf. 2002, 27, 913-928. [CrossRef]

30. De Leo, A.; Ruffini, A.; Postacchini, M.; Colombini, M.; Stocchino, A. The effects of hydraulic jumps instability on a natural river confluence: The case study of the Chiaravagna River (Italy). J. Water 2020, 12, 2027. [CrossRef] 